BIOTROPIA NO. 19, 2002 : 65 - 84

\title{
NOTES ON THE ASTERACEAE OF SUMATERA
}

\author{
SRI SUDARMIYATI TJITROSOEDIRDJO \\ Dept. of Biology, Faculty of Science and Mathematics, Bogor Agricultural University, Jl. \\ Raya Pajajaran, Bogor and South East Asian Regional Center for Tropical Biology \\ (SEAMEO BIOTROP) P.O. Box 116, Bogor, Indonesia.
}

\begin{abstract}
An account of the tribe composition, endemic taxa, comparison with adjacent areas and weedy Asteraceae of Sumatera is given. Based on the records of January 2000, there are 133 species of 74 genera in 11 tribes.

The tribe Heliantheae is the largest, with $28 \%$ of the total number of the genera, followed by Astereae with $15 \%$, Inuleae 12\%, Senecioneae 10\%, Anthemideae, Eupatorieae and Lactuceae 8\%, the other tribes are represented by $4 \%$ or less.

The most diverse genus is Blumea with 14 species. Other genera are only represented by 10 species or less, usually 4 , or 3 , or 2 , and mostly by 1 species only. genera.

Thirty nine or about $53 \%$ are exotic genera and the native ones are less than half of the total number of the

In terms of indigenous and endemic species, Sumatera is richer than Java. There are 1 genus, 7 species and 2 varieties of Asteraceae endemic to Sumatera.

A number of 43 important weed species were introduced from Tropical America, Africa, Asia and Europe. Among these Chromolaena odorata and Mikania micrantha are reported as the most noxious ones.

List of the genera and species recorded in Sumatera is provided in this paper.
\end{abstract}

Key words : Asteraceae/Sumatera/compositions/endemic species/distribution/weedy Asteraceae

\section{INTRODUCTION}

Asteraceae is one of the largest families of flowering plants which has not been revised for the Flora Malesiana (Ross 1993).

This paper is a report on the results of the study on the Asteraceae of Sumatera based on the records up to 2002.

Fundamental work of this family was done by Cassini (1817,1818, 1826-1834), and Bentham (1873) and Bentham \& Hooker (1873). Bentham's tribal classification has stood the test of time, and some modifications were introduced by Hoffmann (1890-1894), Dalla Tore and Harms (1907) and Melchior (1964). Although the 13 tribes recognized by Bentham \& Hoffman have been largely accepted up to the present, they are obviously in need of modification considering recent discoveries in biochemistry, palynology analysis, micromorphology, anatomy, cytology, micromolecular chemistry, and semantide analysis especially cpDNA. Cladistic method has been widely applied, subsequent more precise generic, and tribal concepts have been developed. It has become clear that not only quite a number of genera have been misplaced, but others require a transfer to other tribes (Jeffrey 1995). 
Miquel (1856) made the first revision of the Asteraceae of the Malay Archipelago followed by van Hasselt \& Boerlage (1884), and Boerlage (1891) gave an enumeration of the species. The latest partial revision of the Asteraceae of the Malay Archipelago was made by Koster, who elaborated the tribes Eupatorieae and Vernonieae (Koster 1935, 1941, 1948, 1952, 1953, 1958). She treated 5 species of Adenostemma, 2 of Ageratum, 1 of Centratherum, 2 of Elephantopus, 8 of Eupa-torium , 2 of Ethulia, 1 of Mikania. In total, 57 species were described of which 11 species are introduced. She also revised the Compositae of Java (Koster 1965) and New Guinea (Koster 1966; 1970; 1976; 1979; 1980). van Royen (1983) treated Compositae component of the alpine flora of New Guinea for the species above $3000 \mathrm{~m}$. After these publications, there has been no other comprehensive one on the Asteraceae of Malesia.

The first initial survey of the flora of Sumatera began with the publication of Jack in 1820. It was followed by several authors e.g. Miquel (1856-1861) who published them separately in a number of publications. But after Miquel there has been no attempt yet to bring together the vascular flora of Sumatera. The only exception is the revision of the Euphorbiaceae of Sumatera by Shaw in 1981. Whitmore and Tantra (1986) listed only those species with either a bole of at least $35 \mathrm{~cm}$ diameter, and/ or $20 \mathrm{~m}$ in height, they cited only eight out often species of Vernonia reported for Sumatera by Koster (1935). Vernonia cinerea, $V$. cymosa, V. forbesii, V. patula and V. vagans which were cited by Whitmore and Tantra as a tree are actually herbs, climbers or shrubs. Vernonia is the only genus where four out of the ten species are trees up to $30 \mathrm{~m}$ in height: $V$. arborea, $V$. durifolia, V. patentissim and V. subdentata, while the other six species of Vernonia are herbs or shrubs. Other Asteraceae genera consist of only herbs and shrubs.

Miquel (1861) treated 25 species of 20 genera in 7 tribes of Asteraceae in Sumatera. He described 5 species of Blumea, 2 species of Artemisia, and 1 species of several genera i.e. Adenostemma, Asteromoea, Conyza, Eclipta, Elephantopus, Emilia, Erigeron., Gnaphalium, Gynura, Lagenophora, Microglossa, Myriactis, Sonchus, Sphaeranthus, Wedelia, Vernonia, Xanthium and Youngia.

Boerlage (1891) in his enumeration of the Asteraceae of Sumatera listed 41 species of 28 genera in 8 tribes. He listed 5 species of Blumea, 3 species of Senecio and Vernonia, 2 species of Adenostemma, Anaphalis, Conyza, Wedelia, and 1 species of several genera i.e. Asteromoea, Bidens, Cosmos, Dichrocephala, Eclipta, Emilia, Enydra, Erigeron, Microglossa, Myriactis, Sphaeranthus, Spilanthes and Xanthium.

Koster (1935) in her treatment of the tribes Eupatorieae and Vernonieae in Sumatera described 9 species of Vernonia, 3 species of Adenostemma, 2 species of Ageratum and 1 species of Elephantopus, Mikania and Eupatorium .

Nasution (1984) described 5 species of weedy Asteraceae at the plantations of Aceh and North Sumatera, while Soerjani et al (1987) described 25 species of Asteraceae in the ricefields of Sumatera. In total, there were 69 species of Asteraceae in Sumatera known by several authors: Miquel 1861; Boerlage 1891; Koster 1935 and Soerjani et al. 1987. The records up to December 1998 showed that 
67 genera and 122 species in 10 tribes of Asteraceae in Sumatera were recognized (Tjitrosoedirdjo 2001). Up to January 2000, the author has described 133 species of 74 genera in 11 tribes in Sumatera (Table 1 and Appendix 1).

Four new taxa were recognized by Tjitrosoedirdjo (2002) namely Prenanthes steenisii, Prenanthes sumatrana, Senecio dewildeorum and one variety Emilia sonchifolia var. lanceolata.

In Sumatera, Asteraceae has been recorded in a wide variety of habitats including, montane, highlands, lowlands, fmperata-fields, open spaces of the plantations, and agricultural fields. Representatives may be found in nearly every type of habitat, but few taxa are present in tropical rain forests, swampy, mangrove and aquatic areas. The species are predominantly perennial herbs and shrubs.

\section{MATERIALS AND METHODS}

Herbarium specimens of the Asteraceae of Sumatera and the surrounding islands were studied from several herbaria. The Herbarium Bogoriense (BO) and BIOTROP Herbarium (BIOT) served as the major sources. Most of the specimens at BO were collected during the colonial times, while those at BIOT was gathered after 1970's and some specimens were collected by the author. Selected specimens were kindly obtained on loan from Herbarium of Andalas University ('ANDA') representing taxa from West Sumatera and also some from FRIM (Forest Research Institute Malaysia's/KEP) were also studied. Some specimens of Blumea, Lactuca, and Senecio were provided on loan from the National Herbarium of Netherlands (the former Rijksherbarium:L). Additional specimens were collected during the course of this study from Aceh, North Sumatera, Riau, Jambi, West Sumatera, South Sumatera and Lampung.

Data and information on the morphology, habitat, and distribution were collected from the specimens, literature and field observations.

\section{RESULTS AND DISCUSSIONS}

\section{The Tribe Composition}

Based on the studies up to January 2000, there are 133 species of 74 genera in 11 tribes of Asteraceae in Sumatera that have been recorded (Table 1 \& Appendix 1). There is an increase compared to the records as listed in 1998, where 122 species of 67 genera are in 10 tribes (Tjitrosoedirdjo 2001).

The 11 tribes are Anthemideae, Astereae, Cardueae, Eupatorieae, Heliantheae, Inuleae, Lactuceae, Mutisieae, Senecioneae Tageteae, and Vernonieae. The tribe Cardueae is a new record.

Thirty-nine genera or about 53\% are exotic (Table 1), and the native genera are less than half of the total number of the genera. More than $61 \%$ of these genera 
contain only one species, 9\% have three species and 5\% have 4 species. Others such as Vernonia and Blumea have ten and fourteen species, respectively. Helenieae.

Three tribes are found in Java but not in Sumatera: Arctoctideae, Calenduleae, and

\section{Notes on Distribution of Selected Genera of Asteraceae in Sumatera}

Anaphalis is a genus with a disjunct range distribution: it has been recorded from Europe, Asia and North America. In Sumatera it is represented by two native montane species.

Blumea has an African-Asiatic-Australian range. Most of the species are found in Malesia with 14 in Sumatera which makes it the largest genus in Sumatera. The other genera have 1 to 4 , rarely up to 10 species.

Blumeopsis is a monotypic endemic genus of Eastern Asia. In Malesia, it is only found in Sumatera (Aceh and North Sumatera).

Carpesium is a genus of the northern temperate or subtropical Europe through Asia to Japan. One possibly introduced species has been found in the mountains of Aceh.

Lactuca is a cosmopolitan genus, with three species in Sumatera.

Launaea is a new generic record for Sumatera. Launea sarmentosa was found during the course of this study at a sandy beach near Uelele, Aceh. Kilian (1997) reported that the species has a scattered distribution from East Africa to South China (Guangdong). It is found in the Andaman Nicobars and in Thailand. It is also found in Northeast Australia. In Malesia, it is very rare and until now only known

Table 1. The number of tribes, genera, species, and endemic species/ variety of Asteraceae in Sumatera based on the records up to 2000

\begin{tabular}{|c|c|c|c|c|c|}
\hline No. & Tribes & Name of the genera & $\begin{array}{l}\text { No. of } \\
\text { genera }\end{array}$ & $\begin{array}{l}\text { No. of } \\
\text { species }\end{array}$ & $\begin{array}{l}\text { No. of } \\
\text { endemic } \\
\text { species*/ } \\
\text { variety** }\end{array}$ \\
\hline 1. & Anthemideae & $\begin{array}{l}\text { Achillea*, Artemisia*, Centipeda, } \\
\text { Chrysanthemum*, Cotula, } \\
\text { Leucanthemum* }\end{array}$ & 6 & 8 & - \\
\hline 2. & Astereae & $\begin{array}{l}\text { Aster*, Asteromoea*, Boltonia*, Conyza, } \\
\text { Dihcrocephala, Grangea, Lagenophora, } \\
\text { Microglossa, Myriactis, } \\
\text { Rhynchospermum, Solidago* }\end{array}$ & 11 & 24 & - \\
\hline 3. & Cardueae & Centaurea* & 1 & 1 & - \\
\hline 4. & Eupatorieae & $\begin{array}{l}\text { Adenostemma, Ageratum*, } \\
\text { Austroepatorium*, Chromolaena*, } \\
\text { Eupatorium*, Mikania }\end{array}$ & 6 & 10 & $0 / 1$ \\
\hline
\end{tabular}




\begin{tabular}{|c|c|c|c|c|c|}
\hline No. & Tribes & Name of the genera & $\begin{array}{l}\text { No. of } \\
\text { genera }\end{array}$ & $\begin{array}{l}\text { No. of } \\
\text { species }\end{array}$ & $\begin{array}{l}\text { No. of } \\
\text { endemic } \\
\text { species*/ } \\
\text { variety** }\end{array}$ \\
\hline 5. & Heliantheae & $\begin{array}{l}\text { Acmella, Bidens, Clibadium*, } \\
\text { Coreopsis*, Cosmos*, Dahlia*, Eclipta, } \\
\text { Eleutheranthera*, Enydra, Gaillardia*, } \\
\text { Glossocardia*, Galinsoga*, Helianthus*, } \\
\text { Sigesbeckia*, Sphagneticola, } \\
\text { Synedrella*, Tithonia*, Tridax*, } \\
\text { Wedelia, Xanthium*, Zinnia* }\end{array}$ & 21 & 32 & - \\
\hline 6. & Inuleae & $\begin{array}{l}\text { Anaphalis, Blumea, Blumeopsis, } \\
\text { Carpesium, Gnaphalium, Helichrysum*, } \\
\text { Laggera, Pluchea, Sphaeranthus }\end{array}$ & 9 & 25 & - \\
\hline 7. & Lactuceae & $\begin{array}{l}\text { Lactuca, Launaea*, Prenanthes, } \\
\text { Sonchus*, Taraxacum*, Youngia }\end{array}$ & 6 & 14 & $3 / 0$ \\
\hline 8. & Mutisieae & Ainsliaea, Gerbera* & 2 & 2 & - \\
\hline 9. & Senecioneae & $\begin{array}{l}\text { Cisammpelopsis, Crassocephalum*, } \\
\text { Emilia, Erechtites*, Gynura, Notonia*, } \\
\text { Senecio }\end{array}$ & 7 & 12 & $2 / 1$ \\
\hline 10. & Tageteae & Porophyllum*, Tagetes* & 2 & 2 & - \\
\hline \multirow[t]{2}{*}{11.} & Vernonieae & Elephantopus, Struchium, Vernonia & 3 & 13 & $2 / 0$ \\
\hline & & Total & 74 & 133 & $7 / 2$ \\
\hline
\end{tabular}

Note : * exotic genus

autochthonously in Malesia with the Sumateran collection closing the gap. Its occurrence in Southwest Java and Northwest Australia concurs with the ancient sites of European sailing ships that carried sand as ballast which had been obtained at beaches in East Africa or Sri Lanka. These initially landed in Pelabuhan Ratu (Wijnkoopsbaai) where ballast was removed, or floundered on the shores of Northwest Australia thus introducing the Launaea.

Senecio is the largest genus of Asteraceae, and a very heterogeneous one. Its species are found in all parts of the world. In Sumatera, there are two endemic montane species.

Sonchus is another cosmopolitan and weedy genus. There are three species in Sumatera. Sonchus oleraceous is commonly found the mountain regions in Java. In Sumatera, it is only found in Takengon, Aceh.

Taraxacum is a cosmopolitan genus of weedy species and an extremely complex genus. There are few regularly amphimictic species, some that are occasionally amphimictic, but a vast number appear to be exclusively apomictic, often with 
defective or quite abortive pollen. The apomictic forms are polyploids which have presumably arisen from primary interspesific hybridization. The only species found in Sumatera is tentatively named Taraxacum javanicum here, but may very well represent an undescribed (micro) species.

Vernonia is a wide ranging genus with species in tropical America, Africa, Madagascar. Jones (1979; 1981), followed by Jeffrey (1988), has suggested that actually two main subgenera, if not genera or even subtribes may be involved, an Old World one, Vernonia subgen. Orbivestus, and satellite taxa, and one from the New World, Vernonia s.s. and satellites. If correct, this means that Malesian species attributed to sect. Lepidaploa actually belongs to a possibjy undescribed section. In Sumatera, there are ten species of which two are endemic.

\section{Endemic Taxa and Their Distribution in Sumatera}

The Asteraceae is generally a temperate to subtropical family, yet it forms an important part of the Malesian flora. Being temperate, it is therefore not surprising that the mountain areas in Sumatera are richer in taxa than the lowlands.

Of the 133 species recorded in Sumatera, nearly 50\% have been introduced, while there are only 7 endemic species and 2 endemic varieties (Table 1). These montane endemics are temperate genera and it supports the opinion of van Steenis (1933) that in the tropics such as Malesia, they are restricted to the mountains and represent only small offshoots from their generic centers. When compared for instance with India which has 242 endemic taxa (out of c. 900) the number in Sumatera is very low. In India too many endemics (116) are confined to the montane regions of the Himalayas (Rao \& Dart 1996).

Aceh and West Sumatera showed the highest degree of endemism, apparently due to the considerable areas of high mountains. There are one variety and five species endemic to Aceh i.e. Adenostemma lavenia var. sessilifolium, Senecio dewildeorum, S. sumatranus, Prenanthes steenisii, $P$. stenolimba, and $P$. sumatrana which are concentrated at the Mount Leuser Nature Reserve and its surrounding areas (Fig. 1).

Three endemic species of Prenanthes: P. steenisii, P. stenolimba, and P. sumatrana, have been found in Aceh above $2000 \mathrm{~m}$ altitude (Tjitrosoedirdjo 2002).

In West Sumatera four endemic taxa have been found on the mountains of Kerinci, Merapi, Sago, Talamau and Talang namely Emilia sonchifolia var. Lanceolata, Senecio sumatranus, Vernonia durifolia and Vernonia forbesii. Emilia, sonchifolia var. lanceolata a newly described variety is endemic to Mount Kerinci (Tjitrosoedirdjo 2002).

Jambi, South Sumatera, and Lampung have only one endemic species each, while there are no records of endemics in Bengkulu and Riau.

The two endemic species of Senecio, S. sumatranus and S. dewildeorum have been found at altitudes above $2500 \mathrm{~m}$. Senecio dewildeorum collected by van Steenis from Mount Goh Lembuh, Aceh, and by de Wilde and De Wilde-Duyfjes from Mount Leuser appears to be endemic to the mountain area of Aceh (Tjitrosoedirdjo 2002). 


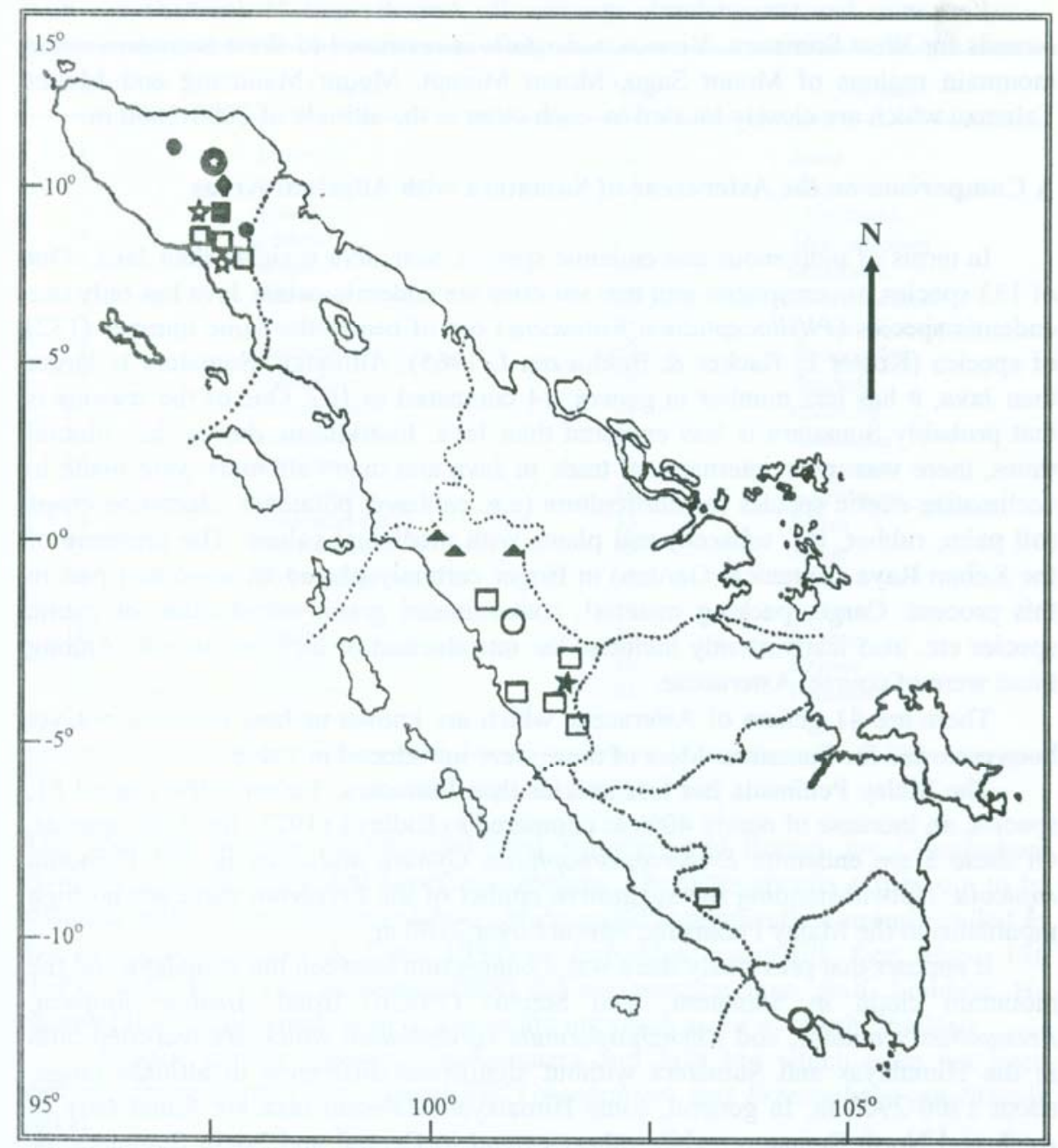

Figure 1. Distribution on the endemic taxa of Asteraceae in Sumatera; Adenostemma lavinia var. subsessilifolium; $\star=$ Emilia sonchifolia var. lanceolata; $\bullet=$ Prenanthes steenisii; $\mathbf{0}=$ Prenanthes stenolimba; $\boldsymbol{\star}=$ Prenanthes sumatrana; $\mathbf{0}=$ Senecio dewildeorum; $\square=$ Senecio sumatranus; $\mathbf{\Delta}=$ Vernonia durifolia; $\mathbf{O}=$ Vernonia forbesii. 
Vernonia, has two endemic species: V. durifolia and V. Forbesii are new records for West Sumatera. Vernonia durifolia is restricted to West Sumatera at the mountain regions of Mount Sago, Mount Merapi, Mount Malintang and Mount Talamau which are closely located to each other at the altitude of $2000-2600 \mathrm{~m}$.

\section{A Comparison on the Asteraceae of Sumatera with Adjacent Areas}

In terms of indigenous and endemic species, Sumatera is richer than Java. Out of 133 species, seven species and two varieties are endemic, while Java has only one endemic species (Phyllocephalum frutescens) out of nearly the same number (132) of species (Koster in Backer \& Bakhuizen f. 1965). Although, Sumatera is larger than Java, it has less number in genera: 74 compared to 107. One of the reasons is that probably Sumatera is less explored than Java. In addition, during the colonial times, there was more international trade in Java and many attempts were made to acclimatize exotic species for horticulture (e.g. cabbage, potatoes), plantation crops (oil palm, rubber, tea, tobacco) and plants with medicinal values. The presence of the Kebun Raya (Botanical Garden) in Bogor certainly played an important part in this process. Cargo, packing material, contaminated grain, introduction of exotic species etc. also inadvertently included the introduction of incipient weeds. Among these were of course Asteraceae.

There are 41 genera of Asteraceae which are known in Java but have not yet been recorded for Sumatera. Most of these were introduced in Table 2.

The Malay Peninsula has less species than Sumatera. Turner (1995) listed 61, species, an increase of nearly $40 \%$ as compared to Ridley's (1923) list of 44 species. Of these 3 are endemic: Erigeron oreophilus, Gynura malaccensis, and Vernonia rupicola. Notwithstanding the suggestive epithet of the Erigeron, there are no high mountains in the Malay Peninsula. Few are over $2100 \mathrm{~m}$.

It appears that previously there was a connection between the Himalaya and the mountain chain in Sumatera. Van Steenis (1933b) listed Ainsliae latifolia, Prenanthes scandens, and Rhynchospermum verticillatum which are recorded both in the Himalayas and Sumatera without significant difference in altitude range, about 1300-2900 m. In general, some Himalayan/Malesian taxa are found only in Aceh and North Sumatera, while others extend to Central and South Sumatera, or even further to Java, South Sulawesi and Nusa Tenggara.

The Leuser complex is especially rich in the Himalayan elements, while there is also a floristic connection over the Kinabalu to Luzon, and over Sulawesi and Seram with New Guinea. It is curious to note that these high-montane species (non-Asteraceae) were able to reach the Leuser complex, but did not venture further down south. The fact that the complex is nonvolcanic while the Bukit Barisan and the mountains in Java are igneous, may offer a clue to this •unsolved question. Other species are apparently not hampered by the occasional devastation that occurs on volcanic summits and were able to travel south.

There are three genera, known in Asia and Sumatera which have not been recorded in Java: Ainsliaea, Blumeopsis, and Prenanthes. Other species known from 
Notes on the Asteraceae ot'Suniatera- Sri Sudarmiyati Tjitrosoedirdjo

Table 2. List of the Asteraceae genera which are known in Java but have not been recorded in Sumatera

\begin{tabular}{rlll}
\hline \hline No. & \multicolumn{1}{c}{ Genera } & No. & Genera \\
\hline 1. & Ambrosia & 22. & Inula \\
2. & Ammobium & 23. & Jaegeria \\
3. & Anacyclus & 24. & Matricaria \\
4. & Anthemis & 25. & Melampodium \\
5. & Artoctis & 26. & Montanoa \\
6. & Athroisma & 27. & Podachaenium \\
7. & Baltimora & 28. & Pseudoelephantopus \\
8. & Bupthalmum & 29. & Pterocaulon \\
9. & Calendula & 30. & Ratibida \\
10. & Callistepus & 31. & Rolandra \\
11. & Calyptocarpus & 32. & Rudbeckia \\
12. & Carthamus & 33. & Sanvitalia \\
13. & Catananche & 34. & Scorzonera \\
14. & Centratherum & 35. & Soliva \\
15. & Chichorium & 36. & Stevia \\
16. & Crossostephium & 37. & Stiffia \\
17. & Cynara & 38. & Stokesia \\
18. & Ethulia & 39. & Silybum \\
19. & Guizotia & 40. & Ursinia \\
20. & Helenium & 41. & Verbesina \\
21. & Helipterum & & \\
\hline
\end{tabular}

Asia and Java but not yet recorded from Sumatera and Borneo are Gnaphalium indicum L., Inula cappa and Senecio araneosus. The latter species turned out to be identical with Cisampelopsis volubilis. Inula cappa is apparently currently called as Synotis cappa (Yeffrey \& Chen 1984) or Duhaldea cappa [PI. Syst. Evol. 176 (1991) 104]. However, Koyama (1988) did not mention Java, Bali, Lombok. He reported that the distribution of /. cappa did not reach as far as North Thailand.

Montane genera known from Sumatera and Java but which have not been recorded from Borneo are : Anaphalis, Gnaphalium, and Prenanthes (van Steenis 1933).

\section{Weedy Asteraceae of Sumatera}

A large number of Asteraceae have been introduced and became naturalized in Sumatera. Most of them were introduced from Tropical America and the others came from elsewhere. Many of the species become an adventive weeds (Table 3). The diversity of climate, soil types, altitude and other factors have favoured the establisment and spread of Asteraceae weeds from many regions of the world. Most of the Asteraceae in Sumatera were introduced during the colonial times, among these were, for instance, the most noxious and dominant Chromolaena odorata and Mikania micrantha. Both species came from tropical America and now have spread to almost all agricultural lands and plantations. 
Table 3. Exotic and important weeds species of Asteraceae in Sumatera with their native country (region) or distribution.

\begin{tabular}{|c|c|c|c|c|c|}
\hline No & Species & $\begin{array}{c}\text { Native } \\
\text { country/origin } \\
\text { or distribution }\end{array}$ & No & Species & $\begin{array}{l}\text { Native } \\
\text { country/origin } \\
\text { or distribution }\end{array}$ \\
\hline 1. & Ageratum conyzoides & $\begin{array}{l}\text { Tropical } \\
\text { America }\end{array}$ & 23. & E. imulifolium & America \\
\hline 2. & A. houstonianum & $\begin{array}{l}\text { Tropical } \\
\text { America }\end{array}$ & 24. & Galinsoga parviflora & $\begin{array}{l}\text { Tropical } \\
\text { America }\end{array}$ \\
\hline 3. & Artemisia vulgaris & Europe & 25. & Gaillardia pulchella & $\begin{array}{l}\text { North } \\
\text { America }\end{array}$ \\
\hline 4. & Acmella paniculata & Asia & 26. & $\begin{array}{l}\text { Grangea } \\
\text { maderaspatana }\end{array}$ & $\begin{array}{l}\text { Tropical } \\
\text { Africa, Asia }\end{array}$ \\
\hline 5. & A. uliginosa & $\begin{array}{l}\text { Europe, S.E. } \\
\text { Asia }\end{array}$ & 27. & Mikania micrantha & $\begin{array}{l}\text { Tropical } \\
\text { America }\end{array}$ \\
\hline 6. & Bidens biternata & America & 28. & M. cordata & Asia \\
\hline 7. & B. pilosa & America & 29. & Porophyllum ruderale & $\begin{array}{l}\text { Tropical } \\
\text { America }\end{array}$ \\
\hline 8. & Centipeda minima & America & 30. & Sonchus arvensis & Europe, Asia \\
\hline 9. & Clibadium surinamense & America & 31. & S. asper & Europe, Asia \\
\hline 10. & $\begin{array}{l}\text { Crassocephalum } \\
\text { crepidioides }\end{array}$ & $\begin{array}{l}\text { Tropical } \\
\text { Africa }\end{array}$ & 32. & S. oleraceus & Europe \\
\hline 11. & Chromolaena odorata & $\begin{array}{l}\text { Tropical } \\
\text { America }\end{array}$ & 33. & Sphaeranthus africanus & Africa \\
\hline 12. & Conyza sumatrensis & America & 34. & S. indicus & Tropical Asia \\
\hline 13. & $\begin{array}{l}\text { Dichrocephala } \\
\text { integrifolia }\end{array}$ & $\begin{array}{l}\text { Tropical } \\
\text { Africa }\end{array}$ & 35. & Sphagneticola trilobata & America \\
\hline 14. & Eclipta prostrata & $\begin{array}{l}\text { Tropical } \\
\text { America }\end{array}$ & 36. & Synedrella nodiflora & $\begin{array}{l}\text { Tropical } \\
\text { Africa }\end{array}$ \\
\hline 15. & Elephantopus mollis & America & 37. & Tithonia diversifolia & $\begin{array}{l}\text { South } \\
\text { America }\end{array}$ \\
\hline 16. & E. scaber & Tropical Asia & 38. & Tridax procumbens & Mexico \\
\hline 17. & $\begin{array}{l}\text { Eleutheranthera } \\
\text { ruderalis }\end{array}$ & America & 39. & Taraxacum javanicum & Java, India \\
\hline 18. & Emilia sonchifolia & $\begin{array}{l}\text { Tropical } \\
\text { Africa, Asia }\end{array}$ & 40. & Vernonia cinerea & $\begin{array}{l}\text { Africa, S.E. } \\
\text { Asia }\end{array}$ \\
\hline 19. & Enydra fluctuans & Cosmopolite & 41. & V. patula & Asia \\
\hline 20. & Erechtites hieraciifolia & $\begin{array}{l}\text { North } \\
\text { America }\end{array}$ & 42. & Xanthium indicum & America \\
\hline 21. & E. valerianifolia & America & 43. & Youngia japonica & $\begin{array}{l}\text { Asia, } \\
\text { Australia }\end{array}$ \\
\hline 22. & $\begin{array}{l}\text { Eupatorium } \\
\text { capillifolium }\end{array}$ & America & & & \\
\hline
\end{tabular}


Among the Sumateran Asteraceae, the records in 1996 showed that there are 32 species considered as weeds (Tjitrosoedirdjo 1996). While in this report based on the observation in 2000, there are 43 species of weedy Asteraceae or thirty two percent of the total number of Asteraceae in Sumatera (Table 3). Four of these species have not been reported before for Sumatera: Eupatorium capilifolium, Son-chus oleraceus, Shagneticola trilobata. and Taraxacum javanicum .

Eupatorium capilifolium found in Payakumbuh, West Sumatera has a potential to become noxious weeds.

Sonchus oleraceous is a native of Europe, North Africa and Continental Asia. It is now a common weed in Java beween 200-2700 m altitude, especially at $800 \mathrm{~m}$ altitude. In Sumatera it is not yet so common. So far it is only known from two collections made in Takengon (Aceh) and in Bukit Gundaling, Berastagi (North Sumatera) at 1200-1400 m altitude.

Sphagneticola trilobata, a native of Central and South America, is usually called Wedelia trilobata. It seems that the plant was introduced and naturalized in Sumatera long time ago where it was used for ground ccrver and as an ornamental plant. It has escaped from these applications and now is a weed at low to high altitudes from Aceh to Lampung. Although it is now common, its occurrence was not reported before or neglected by the botanist collectors.

Taraxacum javanicum was first found in 1996 in North Sumatera at Bukit Gundaling, Berastagi, along a road side at $1400 \mathrm{~m}$ altitude (Tjitrosoedirdjo 310, BIOT). In West Java, it is found in montane areas between 1200-2500 m altitude, where it was first collected in 1888. In view of the tendency in Taraxacum to form local microspecies rapidly this may be an undescribed one, so that a specialist will have to look into this. For this time the name $T$. javanicum is employed here. According to van Soest in Grierson (1980), this Taraxacum species does not belong to the groups of indigenous to Europe as was originally assumed. Taraxacum javanicum has now been found in several parts of India and Sri Lanka. In Java, however, it occurs in tea plantations and it may be introduced through this industry, the same way as it has been introduced in Sri Lanka (Grierson 1980)

Among the three new weedy Asteraceae found in Indonesia reported by Dekker (1981): Acanthospermum hispidum, Calyptocarpus vialis and Elephantopus mollis, only E. mollis was found firstly in North Sumatera in 1980 in S. Bejingkar, Kisaran, North Sumatera (Megia 230, BIOT). It is also known from Sukarami in West Sumatera where it was found in 1987 (Tjitrosoedirdjo 50, BIOT). This species should not be confused with Elepantopus scaber. It has alternate leaves and white flowers, whereas E. scaber L. has rosulate leaves and purple flowers.

Ageratum houstonianum Mill, can easily be mistaken for the closely related A. conyzoides especially because the two are often found in the same habitat. It is also native to tropical America. In Sumatera, it was first fo'und in 1928 by Lorzing (13843, BO) collected in Berastagi, North Sumatera at $1200 \mathrm{~m}$ alt. It has now spread to Sukarami, Solok, West Sumatera at an altitude of $900 \mathrm{~m}$. (Tjitrosoedirdjo 45, BIOT) and Lampung at Batu Keramat, between Gisting and Kota Agung at $500 \mathrm{~m}$ altitude (Tjitrosoedirdjo 415, BIOT). A. conyzoides is commonly found everywhere in Sumatera. 
In Central and South America, the genus Chromolaena has about 165 species, but $C$. odorata is the only species which is now pantropically distributed. In Sumatera, the first collection was made in Deli, Lubuk Pakam in 1932 (van der Meer-Mohr 4004, BO) in tobacco plantations. After the war for independence, it had become quite common and being very distinctive by its white violet flowers, and known as "semak merdeka" (the independence shrubs) or "putihan" (whitish flowers). It has now become an important weed throughout Sumatera.

Clibadium surinamense is another native of South America, and was first reported for Sumatera by Jochems who collected the first specimen in 1932 in tobacco plantations near Medan.

Conyza sumatrensis, which is previously known as Erigeron sumatrensis, is a common weed in open places of fields and plantations, and distributed widely throughout Sumatera.

In Indonesia Crassocephalum crepidioides has been confused with Erechtites valerianifolia (Tjitrosoedirdjo 1987). Jochem (1931) noticed it for the first time in 1926 near Medan. It had probably come from Africa through Sri Lanka and from there to Sumatera (van Steenis 1938). Within a few years, it then rapidly spread over the whole island. In Java it was introduced from Sumatera by tea planters, and it spread widely. It has become even more common than Erechtites hieracifolia and E. valerianifolia which were introduced much earlier. Crassocephalum crepidioides was identified by Backer \& van Slooten (1924) in their "Geillustreerd Handboek der Javaansche Thee-onkruiden (no. 233)" as E. 'valerianifolia', so that many pamphlets, books, publications refer to this species as E. valerianifolia instead of $C$. crepidioides. In the Orient $C$. crepidioides is sometimes confused with E. hieracifolia, as most of the labeled specimens are actually C. crepidioides (Belcher 1955).

The genus Mikania has about 400 species mainly in the warmer parts of the New World. The only indigenous species in Asia is M. cordata , while M. micrantha is the only New World species to have been introduced there. The latter species readily takes to disturb areas and tends to be weedy (Parker 1972). It was imported from Paraguay in 1949 and planted in the Bogor Botanical Garden. In 1956 this species was introduced as a non-legume ground cover in rubber plantations. Wirjahardja (1976) reported that around 1976, it occupied the greater part of rubber plantations and abandoned agricultural areas in West and East Java and South Sumatera. Recently, in West Java and Sumatera, M. cordata could not be found easily since it is suppressed by $M$. micrantha.

Porophyllum ruderale, a native of Mexico and South America, was first reported in Bogor in 1945, a new record for Malesia (Tjitrosoedirdjo 1991). In 1978 the first herbarium specimens from Sumatera were collected from the transmigration areas of Lampung (Dekker \& Wirjahardja 2626, BIOT) and South Sumatera (Dekker \& Wirjahardja 2591, BIOT). Currently, it is commonly found in Sumatera, East and Central Java. Its occurrence has also been reported for Malaysia and Singapore (Tan \& Ibrahim 1992; Turner 1995). 
Some of the weedy species of Asteraceae which is currently not known in Sumatera i.e. Praxelis clematidea (Eupatorium catarium ) and Parthenium hyster-oporus have a potential to become noxious weeds. Praxelis clematidea a native of South America, has been introduced in South China and Queensland, Australia (Veldkamp 1999). Partenium hysterophorus a native of the Carribean Islands has spread to Australia, South Africa, China, the Pasific Islands (Sastroutomo \& Mahyudin 1990). The importation of grass seeds, cover crop seeds, wheat, grains and cattle from Australia might result to the introduction of these weeds in Sumatera. We have to be aware that those species have a potential in spreading rapidly.

\section{CONCLUSIONS}

There are 133 species of 74 genera in 11 tribes of Asteraceae in Sumatera, based on the records in 2000.

The most diverse genus is Blumea with 14 species. Other genera are only represented by 10 species or less, usually 4 , or 3 , or 2 , and mostly by 1 species only.

There are 1 genus, 7 species and 2 varieties endemic to Sumatera

In terms of indigenous and endemic species Sumatera is richer than Java. The high mountain region in Sumatera is shown to be richest in the general Asteraceae flora as well as endemic species..

Thirty nine or about $53 \%$ are exotic genera and the native genera are less than half of the total number. There are 43 important weed species, which were introduced in Sumatera from Tropical America, Africa, Asia and Europe.

The exotic genera and species are introduced and naturalized in Sumatera. The diversity in climate, soil types, altitude and other factors have favoured the establishment and spread of Asteraceae weeds from many regions of the world.

\section{ACKNOWLEDGEMENTS}

Part of the dissertation of the author is supported by TMPD (Team Pengem-bangan Program Doctor) and SEAMEO BIOTROP Bogor, Indonesia, through funding of the DIP project.

The author would like to express her sincere appreciation to all her supervisors , especially Dr. J.F. Veldkamp (L) for his suggestions and comments.

Thanks are also due to the directors of BO, 'ANDA', KEP for giving the facilities to work at their herbarium and $\mathrm{L}$ for the loan specimens.

\section{REFERENCES}

Backer, C.A. 1918. Indische Duinplanten. Trop. Nat. 7: 59

Backer, C.A. \& D.F. van Slooten.1924. Geillustreerd Handboek der Javaansche Thee-onkruiden. Algemeen Proefstation voor Thee. Batavia, Drukkerijen Roygrok \& Co. 
Belcher, R.O. 1955. The Typification of Crassocephalum Moench and Gynura Cass. Kew Bull. 3: 455-465

Bentham, G. 1873. Notes on Classification, History and Geographical Distribution of Compositae. J. Linn. Soc. Bot. 13: 335-577

Bentham, G. \& J.D. Hooker. 1873. Genera Plantarum. 2: 1-224. Lovell Reeve \& Co., London. Boerlage, J.G. 1891.

Flora van Nederlandsch Indie (Compositae). E.J. Brill, Leiden.

Cassini, H. 1816. Troissieme Memoire sur le Synantherees, Analyse de la corolle. J. Phys. Chim. Hist. Nat. Arts. 82: $116-146$

Cassini, H. 1817. Quatrieme Memoire sur la Familie des Synantherees, Contenant 1'analyse de 1'ovaire et de ses Assessoires. J. Phys. Chim. Hist. Nat. Arts 85: 5-21

Cassini, H. 1818. Composees. In G. Cuvier, Diet. Sci. Nat. 10: 131-159

Cassini, H. 1826-1934.Opuscules Phytologiques. 3 Volumes. Paris

Dalla Tore, C.G. de \& H. Harms. 1907. Genera Siphonogamarum. Lipsieae, Berlin.

Dekker, R. J. 1981. Notes on New or Remarkable Indonesian Weed species. Proc. Konp. HIGI Medan.

Jack, W. 1820. The Malayan Miscellanies. Bencoolen

Jeffrey, C. \& Y. L. Chen 1984. Taxonomic Studies on the Tribe Senecioneae (Compositae) of Eastern Asia. Kew Bull. 39, 2:319

Jeffrey, C. 1986. The Senecioneae in East Tropical Africa. Kew Bull. 43: 195-277 Jefrey, C. 1988. The Vernonieae

of East Tropical Africa. Kew Bull. 43:195-277.

Jeffrey, C. 1995. Compositae Systematic 1975-1993. Developments and Desiderata. In Advances in Compositae Systematics D.J. N. Hind, C. Jeffrey \& G.V. Pope (ed.). The Royal Botanic Garden Kew. Vol I.

Jochems, S.C.J. 1931. De invoer van twee nieuwe Composieten in Deli (Gynura sp. en Clibadium surinamense). Trop. Nat. 20: 5-10

Jones, S.B. 1979. Synopsis and pollen morphology of Vernonia (Compositae Vernonieae) in the New World. Rhodora 425-447.

Jones, S.B. 1981. Synoptic Classification and Pollen Morphology of Vernonia (Compositae: Vernonieae) in the Old World. Rhodora 83: 59-75

Grierson, A.J.C. 1980 in Dassanayake, M.D. Revised Handbook of the Flora of Ceylon 1 (111). Amerind, New Delhi.

Hasselt, A.L. van 1884. Bijdragen tot de kennis der flora van midden Sumatra. Flora in Veth. Midden Sumatra 4(2): $1: 49$

Hoffmann, O. 1890-1894.Liguliflorae-Cichorieae in Engler \& Prantl. Die Naturlichen Pflanzenfamilien Kilian, N. 1997. Revision ofLaunaea Cass. (Compositae, Lactuceae, Sonchinae). Englera 17: 288-296 Koster, J.Th. 1935. The Compositae of the Malay Archipelago. Blumea 1(3): 352-538 Koster, J.Th. 1941. Notes on Malay Compositae 1.

Blumea 4(3): 482-492 
Notes on the Asteraceae of Sumatera - Sri Sudarmiyati Tjitrosoedirdjo

Koster, J. Th. 1948. Notes on Malay Compositae II. Blumea 6(1): 264-365

Koster, J. Th. 1952. Notes on Malay Compositae III. Blumea 7(1): 288-291

Koster, J. Th. 1953. Some Annotation to the Compositae Collected by O/Beccari in Borneo \& Sumatra.

Koster, J. Th. 1958. Notes on Malay Compositae IV. Blumea Supplement IV: 170-177

Koster, J. Th. 1965.Compositeae. In Backer and Bakhuizen van den Brink f. Fl. of Java Vol. II: 362-437

Koster, J. Th. 1966. The Compositae of New Guinea I. Nova Guinea Bot. 24: 479-614

Koster, J. Th. 1970. The Compositae of New Guinea II. Blumea 18(10: 137-145

Koster, J. Th. 1975. The Compositae of New Guinea III. Blumea 22(2): 207-217

Koster, J. Th. 1976. The Compositae of New Guinea IV. Blumea 23: 163-175

Koster, J. Th. 1979. The Compositae of New Guinea V. Blumea 25(1): 249-282

Koster, J. Th. 1980. The Compositae of New Guinea VI. Blumea 26(l):233-243

Koyama, H. 1988. Taxonomic Studies in the Compositae of Thailand. Acta Phytotax. Geobot. 39: 161

Melchior, H.A. 1964. Engler's Syllabus der Pflanzen Familien II. Band. Berlin Gebruder Borntragen

Miquel, F.A.W. 1856. Flora van Nederlandsch Indie 2: 1-116. Tweede deel. Fried. Fleischer, Leipzig. Amsterdam, Utrecht.

Miquel, F.A.W. 1861. Flora van Nederlandsch Indie, Eerste bijvoegsel, Sumatra:210-213, 535-537. C.g. van der Post, Amsterdam.

Nasution, U. 1984. Gulma dan Pengendaliannya di Perkebunan Karet Sumatera Utara dan Aceh (Weeds and Their Control in Rubber Plantations in North Sumatera and Aceh) PP4M-Tanjung Morawa (in Indonesian)

Parker, C. 1972. TheMikania Problems. PANS 18(3): 312-315

Rao, R.R. \& B. Datt. 1996. Diversity, Phytogeography of Indian Compositae. In Proceedings Compositae Conference. Vol. I: 445-461.

Ridley, H.N. 1923. The Flora of the Malay Peninsula. L. Reeve \& Co., Ltd. London. Vol. II.: 177-197 Ross, M.C. 1993. Annual Report Foundation Flora Malesiana 1992. Fl. MalesianaBulI.il(2): 131-142 Royen, P. van. 1983. The Alpine Flora of New Guinea 4: 3139-3451. J. Cramer, Vaduz.

Satroutomo, S.S. \& A.A. Mahyudin. 1990. Partenium hysterophorus L. Pest Data Sheet No.: 43. ASEAN Pest Plant Quarantine Center and Training Institute Malaysia.

Shaw, H.K. Airy. 1981. The Euphorbiaceae of Sumatera. Kew Bull. 36(2): 239-373

Steenis, C.G.G.J. van 1933. On the Origin of the Malaysian Mountain Flora. Part 1. Fact and Statement of the Problems. Bull. Jard. Bot. Buit. 13(3): 125-417

Steenis, C.G.G.J. van 1938. Gymtra crepidioides Bth. A recently Introduced weed in S.E. Asia. Current Science VII: 285

Soerjani, M, A.J.G. Kostermans \& G. Tjitrosoepomo. 1987. Weeds of Rice in Indonesia. Balai Pustaka, Jalarta

Tan, H.T.W., Ibrahim, Ali bin \& Chua, K.S. 1992. Addition to the Flora of Singapore I Gard. Bull of Singapore 44: 129 
Tjitrosoedirdjo, Sri S. 1987. Field Characterization of the Confused Species Crassocephalum crepidioides and Erechtites valerianifolia in Indonesia. Proceed. APWSS. Conf. Taipei.

Tjitrosoedirdjo, Sri S. 1991. The Present Status and Potential of Porophyllum ruderale var ruderale in Indonesia. Proc. APWSS Conf. Jakarta.

Tjitrosoedirdjo, Sri S. 1996. Gulma Anggota Suku Asteraceae di Sumatera (The Weedy Asteraceae Species of Sumatera). Proc. HIGI, Bandar Lampung

Tjitrosoedirdjo, Sri S. 2001. Progress on the Studies of Asteraceae in Sumatera. Taxonomy: The Cornerstone of Biodiversity. Proceedings of the Fourth International Flora Malesiana Symposium 1998. Forest Research institute Malaysia, p: 181-186

Tjitrosoedirdjo, Sri S. 2002. Four new taxa of Asteraceae in Sumatera. Reinvvardtia 12 (1): 125-128 Turner, I.M. 1995. A

catalogue of the Vascular Plants of Malaya. Card. Bull, of Singapore 47(1): 168-172

Veldkamp, J.F. 1999. Eupatorium catarium a New Name for Eupatorium clematidea Griseb. Non. Sch. Brp. (Compositae), a South American Species Naturalized and Spreading in S.E. Asia and Queensland, Australia. Card. Bull. Singapore 51(1): 119-124

Whitmore, T.C. \& I.G.M. Tantra. 1986. Tree Flora of Indonesia. Checklist for Sumatra. Forest Research and Development Research Center, Bogor, Indonesia

Wirjahardja, S. 1976. Autecological Study ofMikania spp. BIOTROP Internal Report. 7p. 
List of the genera and species of Asteraceae in Sumatra. Accepted genera and species in bold, synonyms in italic.

\section{Achillea L.}

Achillea millefolium L.

Acmella Rich, ex Pers.

Acmella paniculata (Wall, ex DC.) R.K. Jansen

Spilanthespaniculata Wall, ex DC. Spilanthes acmella auct. non Murr.

Acmella uliginosa (Sw.) R. Cass.

Jaegera uliginosa (Sw.) Baker

Spilanthes iabadicensis A.H. Moore

Spilanthes uliginosa Sw.

Adenostemma Forster \& G. Forster

Adenostemma lavenia (L.) Kuntze

Adenostemma fastigiatum (Blume) DC.

Lavenia vastigiata Blume Verbesina lavenia $\mathrm{L}$.

Adenostemma macrophyllum (Blume) DC.

Adenostemma parviflorum (Blume) DC.

Adenostemma ovatum Miq.

Lavenia parviflora Blume

Ageratum L.

Ageratum houstonianum Mill.

Ageratum conyzoides L.

Ainsliaea DC.

Ainsliaea latifolia (D. Don) Sch. Bip.

Ainsliaeapteropoda DC.

Liatris latifolia D. Don

Anaphalis DC.

Anaphalis javanica (Reinw. ex Blume) Sch. Bip.

Antennaria javanica (Reinw. ex Blume) DC Antennaria saxatilis DC.

Gnaphalium javanicum Reinw. ex Blume

Gnaphalium saxatile Blume

Anaphalis longifolia (Blume) DC.

Gnaphalium longifolium Blume

Artemisia L.

Artemisia scoparia Waldst. \& Kit.

Artemisia vulgaris L. Aster L.

Aster novae-angliae L.

Symphyotrichum novae-angliae (L.) Nesom

Virgulus novae-angliae (L.) Reveal \& Keener

Aster novi-belgii L.

Symphyotrichum novi-belgii (L.) Nesom

Asteromoea Blume

Asteromoea indica (L.) Blume

Aster indicus L.

Boltonia indica (L.) Benth.
Austroeupatorium R M. King \& H. Rob.

Austroeupatorium inulifolium (Kunlh) R.M.

King \& H. Rob. Eupatorium inulifolium Kunth

Eupatorium javanicum auct. non Blume

Eupatorium pallescens DC.

Bidens L.

Bidens biternata (Lour.) Merr. \& Sherrf ex Sherff

Bidens chinensis (L.) Willd.

Coreopsis biternata Lour.

Bidens pilosa C Blumea DC.

Blumea balsamifera (L.) DC.

Blumea grandis (Wall.) DC.

Conyza balsamifera L.

Blumea bicolor Merr.

Blumea clarkei Hook. F.

Blumea lessingii Merr.

Blumea densitlora DC

Blumea hieraciifolia (D. Don) DC.

Blumea chinensis Walpers

Blumea subsericans

Elmer Erigeron hieraciifolius D. Don

Blumea intermedia J. Koster

Blumea junghuhniana (Miq.) Boerl.

Blumea dacycoma (Miq.) Boerl.

Conyza dacycoma Miq.

Conyza junghuhniana Miq.

Blumea korthalsiana (Miq.) Boerl.

Conyza korthalsiana Miq.

Blumea lacera (Burm. f.) DC.

Blumea lactucifolia DC.

Blumea runcinata DC.

Conyza lacera Burm. f.

Blumea laciniata (Roxb.) DC.

Blumea crepidifolia DC.

Blumea javanica (Blume) Zoll.

Blumea runcinata DC.

Blumea sonchifolia DC.

Conyza javanics Blume

Conyza laciniata Roxb.

Blumea lanceolaria (Roxb.) Druce

Blumea laxiflora Elmer

Blumea longifolia DC.

Blumea myriocephala DC.

Blumea spectabilis DC.

Conyza lanceolaria Roxb.

Blumea riparia (Blume) DC. 
Blumea semivestita DC.

Conyza riparia Blume

Blumea sylvatica (Blume) DC.

Blumea sessilifolia (Blume) DC.

Conyza sessilifolia Blume

Conyza sylvatica Blume

Blumea tenella DC

Blumea humifusa (Miq.) Boerl.

Conyza humifusa Miq.

Blumeopsis Gagnep.

Blumeopsis flava (DC.) Gagnep.

Blumea flava DC.

Blumeopsiafalcata auct. non Merr.

Laggera flava (DC.) Benth.

Boltonia L'Her

Boltonia asteroides (L.) L' Her

Matricaria asteroides L.

Carpesium L.

Carpesium cernuum L.

Centaurea L.

Centipeda Lour.

Centipeda minima (L.) A. Br. \& Aschers.

Artemesia minima L.

Centipeda minuta (G.Forst.) Benth. ex CB.

Clark

Centipeda orbicularis Lour.

Cotula minima (L.) Willd.

Cotula minuta G. Forst.

Grangea minima (L.) Poir

Chromolaena DC.

Chromolaena odorata (L.) R.M. King \& H. Rob.

Eupatohum odoratum L.

Chrysanthemum L.

Chrysanthemum coronarium $L$.

Bupthalmum oleraceum Lour.

Chrysanthemum roxburghii (Desf.) DC.

Glebionis coronaria (L.) Tzvel.

Pyrethrum roxburghii Desf.

Chrysanthemum morifolium Ramat.

Matricaria morifolia Ramat.

Pyrethrum sinense (Sabine) DC.

Cissampelopsis (DC.) Miq.

Cissampelopsis volubilis (Blume) Miq.

Cacalia volubilis Blume

Senecio araneosus DC.

Senecio blumei DC.

Senecio walkeri auct. non Arn.

Clibadium Allamand ex L.

Clibadium surinamense $\mathrm{L}$.

Conyza Less.

Conyza japonica (Thunb.) Less, ex DC.

Escenbachiajaponica (Thunb.) J. Koster

Conyza leucantha (D. Don) Ludlow \& Raven

Blumeopsis falcate (D. Don) Merr.
Conyza vicidula Wall, ex DC.

Escgenbachia vicidula (DC.) J. Koster

Erigeron falcatum D. Don

Erigeron leucanthum D. Don

Conyza sumatrensis (Retz.) Walker

Erigeron sumatrensis Retz.

Erigeron linifolius auct. non Willd.

Coreopsis L.

Coreopsis grandiflora Hogg ex Sweet

Coreopsis tinctoria Cav.

Cosmos Cav.

Cosmos bipinnatus Cav.

Cosmos caudatus Kunth

Cosmos sulfureus Cav.

Bidens. sulfurea (Cav.) Sell. Bip.

Cotula L.

Cotula anthemoides $L$.

Crassocephalum Moench.

Crassocephalum crepidioides (Benth.) S.

Moore

Crassocephalum diversifolium Hiern

Gynura crepidioides Benth.

Dahlia Cav.

Dahlia pinnata auct. non Cav.

Dicrocephala L. Her. ex DC

Dicrocephala integrifolia (L.f.) Kuntze

Cotula bicolor Roth

Dicrocephala bicolor (Roth) Schlechtend.

Dicrocephala latifolia (Pers,) DC.

Grangea latifolia (Pers) Poir.

Eclipta L.

Eclipta prostrata (L.) L.

Eclipta alba Hassk.

Eclipta erecta L.

Verbesina prostrate L.

Elephantopus L.

Elephantopus mollis Kunth

Elephantopus martii Graham ex Sch. Bip.

Elephantopus lomentosus auct. non L.

Elephantopus sea her L.

Eleutheranthera Poit.

Eleutheranthera ruderalis (Sw.) Sch. Bip.

Eleutheranthera. prostrata (Sw.) Sch. Bip.

Kegelia ruderalis Sch. Bip.

Melampodium ruderale Sw.

Ogiera ruderalis (Sw.) Griseb.

Emilia Cass.

Emilia coccinea (Sims) G. Don

Cacalia cocinea Sims

Cacalia sagitata Willd.

Emilia javanica auct. non C.B. Rob.

Emilia sagittata DC.

Emilia prenanthoidea DC.

Emilia sonchifolia (L.) DC.

Cacalia sonchifolia L. 
Crassocephalum sonchifolium (L.) Less. Emilia purpurea Cass.

Emilia rigidula DC.

Enydra Lour.

Enydra fluctuans Lour.

Meyerafluctuans (Lour.) Spreng.

Erechtites Raf.

Erechtites hieraciifolia (L.) Raf. ex DC.

Senecio hieraciifolius L.

Erechtites valerianifolia (Wolf) DC.

Crassocephalum valerianifolium Less.

Erechtites petio/ata auct. non Benth.

Gymtra rosea Ridl.

Eupatoriutn L.

Eupatorium capillifolium (Lam.) Small

Artemesia capillifolia Lam.

Chrysosoma capillacea Michx.

Eupatorium foenicoloides Walt.

Gaillardia Foug.

Gaillardia pulchella Foug.

Galinsoga Ruiz \& Pavon

Galinsoga parvillora Cav.

Gerbera Cass.

Gerbera jamesonii Bolus ex Adlam

Glossocardia Cass.

Glossocardia leschaenaultii (Cass.) Veldk.

Chrysanthellum indicum auct. non DC.

Chrysanthellum leschenaultii (R. Cass.) Backer ex Kostcr

Chrysanthellum procumbens auct. non L.C.M. Rich.

Gnaphalium L.

Gnaphalium japonicum Thunb.

Gnaphalium pensylvanicum Willd.

Gamochaetapensylvanicum (Willd.) Cabrera

Gnaphalium perigrinum Fern.

Granges Adans.

Grangea niaderaspatana (L.) Poir.

Artemesia maderaspatana L.

Gynura Cass.

Gynura aurantiaca (Blume) DC.

Gynura densiflora Miq.

Gynura lyrata Sch. Bip. ex Miq.

Gynura mollis Sch. Bip ex Zoll.

Gynura sumatrana Miq.

Gynura procumbens (Lour.) Merr.

Cacalia procumbens Lour.

Cacalia sarmentosa Blume

Gynura sarmentosa (Blume) DC.

Helianthus L.

Helianthus angustifolius L.

Helianthus annuus $\mathrm{L}$.

Helianthus tuberosus L.

Hclichrysum Mill.

Helichrysum orientale (L.) Gaertn.
Gnaphalium orientale L.

Lactuca L. Lactuca indica L.

Pterocypsela indica (L.) C. Shih

Lactuca laevigata (Blume) DC.

Aracium laevigatum (Blume) Miq.

Ixeridium laevigatum (Blume) Pak \& Kawano

Prenanthes laevigata Blume

Lactuca saliva L. Launaea Cass.

Launaea sarmentosa (Willd.) Sch. Bip. ex Kuntze

Ammoseris sarmentosus (Willd.) DC.

Lactuca sarmentosa (Willd.) DC.

Launaea pinnatifida Cass.

Prenanthes sarmentosa Willd.

Laggera Sch. Bip. ex Koch

Laggera alata (D. Don) Sch. Bip. ex Oliver

Blumea alata (D. Don) DC.

Conyza alata (D. Don) Roxb.

Erigeron alatum D. Don

Lagenophora Cass.

Lagenophora lanata A. Cunn.

Lagenophora gracilis Steetz

Lagenophora stipitata auct. Druce

Lagenophora sundana Miq.

Leucanthemum Mill.

Leucanthemum vulgare Lam.

Chrysanthemum leucanthemum $\mathrm{L}$.

Microglossa DC.

Microglossa pyrifolia (Lam.) Kuntze

Conyzaprolifera Blume

Conyza pyrifolia Lam.

Mycroglossa volubilis DC.

Mikania Willd.

Mikania cordata (Burm.f.) B.L. Rob.

Eupatorium cordatum Burm. f.

Eupatorium volubile Vahl.

Mikania scandens auct. non Willd.

Mikania volubilis (Vahl.) Willd.

Mikania micrantha Kunth

Myriactis Less.

Myriactis javanica (Reinw. ex Blume) DC.

Bellisjavanica Reinw. ex Blume

Notonia DC.

Notonia grandiflora Wall, ex DC.

Senecio grandiflorus (DC.) Jacobsen

Senecio indicus Backer ex Heyne

Pluchea Cass.

Pluchea indica (L.) Less.

Baccaris indica L.

Porophyllum Guett.

Porophyllum ruderale (Jacq.) Cass.

Cacalia ruderalis (Jacq.) Sw. 
Kleinia ruderalis Jacq.

Porophyllum ellipticnm Cass.

Prenanthes L.

Prenanthes scandens Hook. F. ex Benth.

Prenanthes steenisii Tj.

Prenanthes stenolimba Steenis

Prenanthes sumatrana $\mathrm{Tj}$.

Rhyncospermum Blume

Rhyncospermum verticillatum Reinw. ex Blume

Senecio L.

Senecio dewildeorum $\mathrm{Tj}$.

Senecio sumatranus Martelli

Senecio korintjianus Boerl.

Sigesbeckia L

Sigesbeckia orientalis L.

Solidago L.

Solidago canadensis L.

Sonchus L.

Sonchus arvensis $\mathrm{L}$.

Sonchus asper (L.) Hill.

Sonchus malaianus Miq.

Sonchus oleraceus L

Sphaeranthus L.

Sphaeranthus africanus L.

Sphaeranthus indicus L.

Sphagneticola O. Hoffm.

Sphagneticola calendulacea (L.) Pruski

Complaya chinensis (Osbeck) Strother

Telechitonia chinensis (Osbeck) H. Rob. \& Cuatrecasas

Verbesina calendulacea L,

Wedelia calendulacea (L.) Less.

Wedelia chinensis (Osbeck) Merr.

Sphagneticola trilobata (L.) Pruski

Complaya trilobata Strother

Seruneum trilobatum (L.) Kuntze

Silphium trilobatum L.

Thelechitonia trilobata (L.) H. Rob. \&

Cuatrecasas

Wedelia trilobata (L.) A. Hitchc.

Struchiuni P. Br.

Struchium sparganophorum (L.) Kuntze

Ethulia sparganophora L.

Ethulia struchium Sw.

Sparganophorus vailantii Crantz

Sparganophorus struchium Poir.

Synedrella Gaertn.

Synedrella nodiilora (L.) Gaertn.

Verbesina nodiflora L.

Tagetes L.

Tagetes erecta L.

Tagetes major Gaertn.

Taraxacum Wigger

Taraxacum javanicum Soest.
Taraxacum offlcinale Wigger

Tridax L

Tridax procumbens L.

Tithonia Desf. ex Juss.

Tithonia diversifolia (Hemsl.) A. Gray

Mirasolia diversifolia Hemsl.

Urbanisol tagetiflora (Desf.) Kuntze

Tithonia rotundifolia (Mill.) S.F. Blake

Tagetes rotundifoliaM॥I. Desf.

Tithonia tagetiflora Desf.

Vernonia Schreb.

Vernonia arborea Buch.-Ham.

Gynanthemum arboreum (Buch.-Ham) H. Rob.

Strobocalyx arborea (Buch.-Ham) Sch. Bip.

Vernonia cinerea (L.) Less.

Conyza cinerea L.

Cyabthillium cinereum (L.) H. Rob.

Senecioedes cinerea (L.) Post \& Kuntze

Vernonia coronata J. Koster

Vernonia cymosa Blume

Vernonia durifolia J. Koster

Vernonia forbesii S. Moore

Vernonia patcntissima J Koster

Vernonia patula (Dryand.) Merr.

Conyza patula Dryand.

Cyanthillium villosum Blume

Vernonia chinense (Less.) Less.

Vernonia subdentata J. Koster

Vernonia vagans DC.

Gymnanthemum vegans DC.

Wedelia Jacq.

Wedelia biflora (L.) DC.

Seruneum biftorum (L.) Kuntze

Seruneum strigulosum (K. Schum.) Kuntze

Wolastonia biflora (L.) DC.

Wolastonia slrigulosa (K. Schum.) Kuntze

Wedelia montana (Blume) Boerl.

Seruneum montanum (Blume) Kuntze

Wolastonia Montana Blume

Verbesina Montana Blume

Wedelia urticifolia (Blume) DC.

Seruneum urticifolium (L.) Kuntze

Verbesina urticifolia Blume

Wolastonia urticifolia (Blume) Hassk.

Xanthium L.

Xanthium indicum Koenig. ex Roxb.

Xanthium inequilaterum DC.

Youngia Cass.

Youngia japonica (L.) DC.

Zinnia L.

Zinnia elegans Jacq. 